\title{
PERSEPSI KONSUMEN DALAM KEPUTUSAN PEMBELIAN TERHADAP PRODUK - PRODUK OLAHAN SALAK (Studi Kasus UD.SALACCA)
}

\author{
Sry Lestari \\ Institut Agama Islam Negeri Padangsidimpuan \\ Jalan T. Rizal Nurdin Km. 4,5 Sihitang, Padangsidimpuan \\ Email: srylestarimdf5@gmail.com
}

\begin{abstract}
Abstrak,
Produsen pengolahan salak dalam hal ini UD. Salacca perlu meneliti persepsi konsumen dalam hal kepuasan pembelian produk olahan salak dan hal- hal yang memengaruhinya untuk mengatasi persaingan perusahaan. Hal- hal yang memengaruhi keputusan pembelian konsumen yang diteliti adalah kualitas produk, harga, dan faktor sosial. Tujuan penelitian adalah untuk mengetahui persepsi konsumen UD. Salacca terhadap faktor- faktor yang memengaruhi keputusan pembelian produk olahan salak, untuk mengetahui tahapan konsumen beralih memilih produk olahan salak dibandingkan dengan salak segar dan untuk mengetahui cara konsumen mendapatkan informasi produk olahan salak. Pendekatan penelitian adalah kualitatif deskriptif dengan mewawancarai konsumen langsung. Persepsi konsumen UD. Salacca terhadap produk olahan salak ternyata positif. Artinya, konsumen tetap membeli salak segar meskipun membeli produk olahan salak karena faktor yang memengaruhi konsumen memilih produk olahan salak bukan karena harga dan kualitasnya melainkan karena kondisi konsumen tersebut.
\end{abstract}

Kata Kunci: Kualitas Produk, Harga, Faktor Sosial, Keputusan Pembelian

\begin{abstract}
,
Zalacca processing producers in this case UD. Salacca need to examine consumer perceptions in terms of the purchase decision of salak processed products, the things that influence them to win the competition. The things that influence consumer purchasing decisions examined in this study are product quality, price, and social factors. The purpose of this study was to determine the perception of UD. Salacca consumers on the factors that influence the decision to purchase processed zalacca products, to find out the stages of consumers switching to choose processed products compared to fresh salak, to find out how consumers get information on processed zalacca products. UD. Salacca's consumer perception of salak processed products is positive. Consumers continue to buy fresh salak even though they buy processed zalacca products they also buy fresh zalacca. The thing that influence consumers to decide buying both not only because of price and quality but also the condition of the consumer.
\end{abstract}

Keywords: Product Quality, Price, Social Factor, Consumer Purchasing Decision 


\section{PENDAHULUAN}

Bisnis food and beverage merupakan bisnis yang terus mengalami pertumbuhan. Hal ini dikarenakan makanan dan minuman merupakan kebutuhan pokok yang harus dipenuhi oleh setiap manusia. Terlebih lagi, masyarakat saat ini memiliki kecenderungan untuk mengonsumsi makanan yang siap untuk dikonsumsi atau ready to eat. Hal ini memberikan dampak positif terhadap pertumbuhan omzet makanan dan minuman olahan di Indonesia sehingga menjadi peluang besar, tetapi juga berarti bahwa persaingan untuk memasuki maupun bertahan di bisnis bidang kuliner semakin ketat. Masyarakat semakin cerdas tidak hanya melihat tampilan produk tapi sudah sampai pada tingkat manfaat konsumsi, kehalalan, kualitas produk, harga, bahkan sampai pada faktor sosial dalam keputusan pembelian konshmen.

Bisnis tidak terlepas dari aktivitas produksi pembelian penjualan, maupun pertukaran barang dan jasa yang melibatkan orang atau perusahaan. Aktivitas bisnis pada umumnya mempunyai tujuan menghasilkan laba, serta mengumpulkan cukup dana bagi kegiatan bisnis itu sendiri. Melihat peluang ini maka didirikanlah suatu usaha yang bergerak dibidang pengolahan buah salak.

Salak merupakan buah unggulan dari Kabupaten Tapanuli Selatan dan Kota Padangsidimpuan. Akan tetapi produk olahan buah salak mulai dikenal di daerah Kabupaten Tapanuli Selatan dan Kota Padangsidimpuan sekitar tahun 2008 seperti: manisan salak, dodol salak, kurma salak, dan kripik salak. Semenjak saat itu, mulai muncul lebih banyak produk olahan hingga saat ini. Sedangkan buah salak atau salak segar sudah lama eksis di daerah tersebut. Dari keadaan tersebut dapat dilihat konsumen lebih mengenal buah salak segar dibandingkan produk olahan buah salak.

Ada beberapa usaha pengolahan buah salak diantaranya Koperasi Agrina, Bolu Salak Kenanga dan UD. Salacca. Beberapa jenis produk olahan salak yang dihasilkan dapat dilihat pada Tabel 1.

Tabel 1. Produk Olahan Salak 


\begin{tabular}{|l|l|l|}
\hline \multicolumn{1}{|c|}{ Koperasi Agrina } & \multicolumn{1}{|c|}{ Bolu Salak } & \multicolumn{1}{c|}{ UD. Salacca } \\
\hline Dodol Salak & Bolu Salak dengan beberapa variant & Dodol Salak \\
Kurma Salak & topping & Kurma Salak \\
Kripik Salak & & Kripik Salak \\
Sirup Salak & & Sirup Salak \\
Madu Salak & & Madu Salak \\
Nagogo Drink & & Nagogo Drink \\
& & Agar- agar Salak \\
& & Kecap salak \\
& & Bakso salak \\
& & Kopi Salak \\
& & Sari Salak \\
& & Manisan Salak \\
& & \\
\hline
\end{tabular}

Sumber: Wawancara dengan pengusaha pengolahan salak

Berdasarkan Tabel 1. dapat diketahui bahwa UD. Salacca memiliki lebih banyak variasi produk olahan buah salak yaitu sebanyak dua belas dibandingkan dengan produsen lainnya. Hal ini menjadi penyebab konsumen memiliki lebih banyak pilihan ketika memutuskan ingin membeli produk olahan salak. Hal inilah yang mendorong peneliti untuk melakukan penelitian dengan judul "Persepsi Konsumen dalam Keputusan Pembelian terhadap

\section{Produk - Produk Olahan Salak (Studi Kasus UD. Salacca).”}

Rumusan masalah dari penelitian ini adalah (1) bagaimana persepsi konsumen terhadap faktor- faktor yang mempengaruhi keputusan pembelian produk olahan salak? (2) bagaimana konsumen beralih memilih produk olahan dibandingkan dengan salak segar? (3) bagaimana konsumen mengetahui produk olahan salak?

Adapun tujuan dari penelitian ini adalah (1) untuk mengetahui persepsi konsumen terhadap faktor- faktor yang mempengaruhi keputusan pembelian produk olahan salak; (2)untuk mengetahui tahapan konsumen beralih memilih produk olahan dibandingkan dengan salak segar dan; (3) untuk mengetahui cara konsumen mendapatkan informasi produk olahan salak.

\section{TINJAUAN TEORITIK}

\section{Persepsi}

Persepsi merupakan salah satu aspek psikologis yang penting bagi manusia dalam merespon kehadiran berbagai aspek dan gejala sekitarnya. Persepsi mengandung pengertian yang sangat luas, menyangkut intern dan ekstern. Berbagai ahli telah memberikan definisi yang beragam tentang persepsi, walaupun pada prinsipnya mengandung makna yang sama. Menurut Kamus Besar Bahasa Indonesia, persepsi adalah tanggapan (penerimaan) langsung dari sesuatu. Proses seseorang mengetahui beberapa hal melalui panca inderanya. Persepsi 
didefinisikan sebagai gambaran tentang sesuatu objek yang menjadi fokus permasalahan yang dihadapi (Tampubolon, 2008).

\section{Konsumen}

Seorang pemasar maupun penjual seharusnya mengetahui apa keinginan dan harapan pelanggan atau konsumen. Keinginan dan harapan mereka adalah: (1) bebas membuat keputusan, (2) memperoleh hasil sesuai keinginan, (3) mempertahankan harga diri, (4) diperlakukan secara adil, (5) diterima dan disambut secara baik, (6) diberi tahu segala sesuatu yang terjadi, (7) merasa aman dan dilindungi haknya, (8) di dudukkan sebagai orang penting, (9) menuntut keadilan.

\section{Tipe-tipe Konsumen.}

\section{Tipe-tipe konsumen menurut Ernerst Kretschmer}

Ernerst Kretschmer, berdasarkan hasil penelitianya menyimpulkan adanya korelasi positif antara bentuk tubuh manusia dengan prilakunya. Dalam hubungannya dengan prilaku konsumen, Ernerst Kretschmer mengategorikan tiga tipe konsumen, yaitu tipe piknis, tipe leptosome, dan tipe atletis.

a. Konsumen tipe piknis

Tipe ini menunjukkan bentuk badan bulat, anggota badan pada umumnya agak pendek, dan wajahnya bulat lebar. Karakter tipe piknis ada yang menunjukkan sifat pemarah dan suka berbicara tenang, dan suka humor; ada pula yang sifatnya pendiam, baik hati serta yang bersifat praktis energetik.

Adapun cara menghadapi atau melayani tipe piknis antara lain adalah:

- Perhatikan suasana hatinya, dan usakan untuk berbincang-bincang jika kelihatan ia menghendakinya.

- Lakukan percakapan yang menarik, ramah dan sedikit humor

- Jangan mengadakan debat kusir karena pada umumnya mereka mempunyai kemampuan "bersilat lidah".

- Untuk tipe piknis yang pendiam, sebaiknya beri perhatian dengan cara mengucapkan, misalnya, “ Ada yang perlu dibantu Pak, Bu, Oom, Tante ?”

- Jika mereka menunjukkan perilaku tertentu yang kurang pantas didengar, janganlah dipersoalkan karena mereka pada dasarnya suka humor.

b. Konsumen tipe leptosome

Tipe ini menunjukkan bentuk tubuh agak kecil dan lemah, bahu tanpak kecil, leher dan anggota badan menunjukkan kesan kurus panjang. Karakter tipe leptosome ada yang menunjukkan orang angkuh, orang idealis.

Adapun cara menghadapi atau melayani tipe ini antara lain adalah: 
- Hormatilah mereka seperti seorang raja yang harus siap dilayani.

- Bersikaplah sabar, hormat, bijaksana dan menurut perintahnya.

- Jangan menegur mereka dengan cara yang kurang enak, tetapi sapalah mereka dengan sikap hormat, tunduk kepda mereka.

c. Konsumen tipe atletis

Tipe ini menunjukkan bentuk badan kokoh, pundak tanpak lebar, dan pinggul berisi. Anggota badannya cukup panjang, badan berotot dan kekar. Wajahnya bulat telur dan lonjong. Karakternya menunjukkan sikap banya gerak, tetapi penampilannya kalem, jarang humor, dan mempunyai sifat lekas tidak percaya dan kaku.

Adapun cara menghadapi atau melayani tipe ini antara lain adalah:

- Hindarilah berdiskusi atau berdebat kusir.

- Berilah kesan seakan-akan mereka adalah orang yang pandai.

- Bersabarlah dan janganlah menunjukkan sikap terburu-buru kepada mereka.

- Sebaiknya, jika ada pertanyaan yang mereka kemukakan, hendaknya dijawab dengan penjelasan yang sistematis dan kalau memungkinkan, dengan alat peraga, karena mereka pada umumnya tidak cepat percaya.

- Hindarkanlah sikap yang mengecewakan mereka, terutama jika mereka tidak jadi memberi barang.

\section{Perilaku konsumen dalam Islam}

Dalam Islam, proses dalam perilaku konsumen ini terdapat dalam beberapa ayat Alquran yang bersifat umum, artinya bisa diterapkan dalam segala aktifitas. selain itu konsep perilaku konsumen dalam Islam lebih ditekankan pada sikap mengkonsumsi makanan dan minuman yang halal dan baik. Dan sebagaimana dalam Q.S Al-Baqarah ayat 168 sebagai berikut:

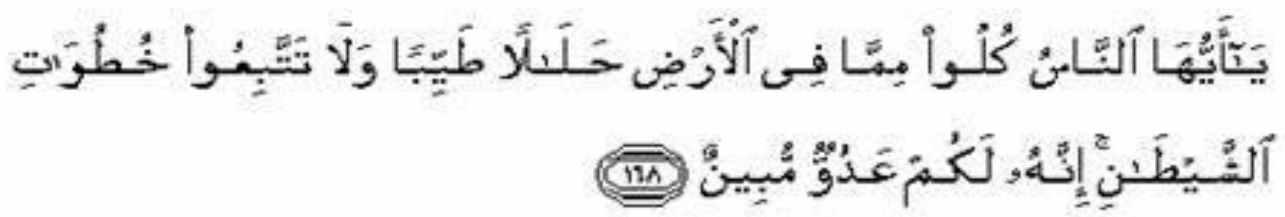

Artinya: Hai sekalian manusia, makanlah yang halal lagi baik dari apa yang terdapat di bumi, dan janganlah kamu mengikuti langkah- langkah syaitan; karena sesungguhnya syaitan itu adalah musuh yang nyata bagimu.

Dari pengertian ayat di atas menjelaskan bahwa perintah kepada seluruh manusia untuk tidak memakan makanan yang haram. Namun demikian tidak semua makanan yang 
halal otomatis baik. Karena kondisi tubuh setiap orang berbeda, makanan baik bagi seseorang belum tentu makanan yang baik buat yang lainnya.

\section{Kualitas}

Kualitas adalah totalitas dari fitur- fitur dan karakteristik atas sebuah produk atau jasa yang memiliki kemampuan untuk memuaskan atau memenuhi kebutuhan (Kotler dan Keller, 2012). Produk adalah segala sesuatu yang dapat ditawarkan kepasar untuk diperhatikan, dibeli, digunakan, dikonsumsi ang dapat memuaskan keinginan dan kebutuhan (Kotler dan Amstrong, 2010). Menurut Fiani dan Japarianto, 2012) terdapat 9 indikator untuk mengukur kualitas makanan:

1. Warna, warna dari bahan- bahan makanan harus dikombinasikan sedemikian rupa supaya tidak terlihat pucat atau warnanya tidak serasi.

2. Penampilan, makanan harus terlihat baik saat disajikan, dimana hal tersebut adalah suatu faktor yang penting.

3. Porsi, memiliki porsi standar dalam stiap penyajian makanan

4. Bentuk, bentuk makanan memainkan peranan penting dalam daya tarik mata. bentuk makanan yang menarik bisa diperoleh lewat cara pemotongan yang bervariasi.

5. Temperatur, mampu mempengaruhi rasa dari sebuah makanan, misalnya rasa manis, pada sebuah makanan akan lebih terasa saat makan tersebut masih hangat, sementara rasa ain pada sup akan kurang terasa saat sup masih panas.

6. Tekstur, ada banyak tekstur dalam makanan seperti halus atau tidak, cair atau padat, keras atau lembut, kering atau lembab, dan lain- lain.

7. Aroma merupakan reaksi dari makanan yang mempengaruhi konsumen menikmati makanan.

8. Tingkat kematangan, tekstur dari makanan dapat dipengaruhi oleh tingkat kematangan.

9. Rasa, terdapat berbagai, macam rasa, yaitu manis, asam asin, dan pahit, makanan haruslah memiliki rasa sedap untuk dinikmati.

\section{Harga}

Harga adalah sejumlah uang yang ditukarkan untuk produk atau jasa (Fure, 2013). Terdapat indikator- indikator mengenai harga yang dapat mempengaruhi keputusan pembelian konsumen (Purwati et al., 2012):

1. Keterjangkauan harga sesuai dengan daya beli masyarakat

2. Fleksibilitas pembayaran, cara pembayaran yang flesibel.

3. Potongan harga, memberikan potongan harga atau diskon atau cash back pada pembelian produk. 
4. daya saing harga, kemampuan harga produk untuk bersaing.

\section{Faktor Sosial}

Faktor sosial adalah segala sesuatu yang dipakai sebagai acuan dalam berinteraksi antar manusia dalam konteks masyarakat atau komunitas dan berfungsi untuk mengatur tindakan- tindakan yang dimunculkan oleh individu- individu sebagai anggota suatu masyarakat (Urfana dan Sembiring, 2013).

Menurut Kotler dan Keller (Kotler dan Keller, 2012) faktor sosial mencakup:

1. Kelompok referensi, adalah semua kelompok yang memiliki pengaruh langsung maupun tidak langsung terhadap perilaku atau sikap seseorang.

2. Keluarga, adalah kelompok konsumen yang paling penting karena seperti halnya orang tua mampu memberikan dampak atas perilaku seseorang secara signifikan.

3. Peran dan status. Seseorang memilih merek produk yang mencerminkan peran dan statusnya dalam masyarakat

\section{Keputusan Pembelian Konsumen}

Menurut Oladepo dan Abimbola (Oladepo dan Abimbola, 2015), keputusan pembelian konsumen adalah serangkaian pilihan yang telah dibuat oleh konsumen sebelum melakukan pembelian. Terdapat 5 proses keputusan pembelian konsumen (Kotler dan Keller, 2012):

1. Pengenalan masalah. Proses pembelian dimulai ketika konsumen menyadari bahwa ada masalah atau kebutuhan yang dipicu oleh rangsangan internal maupun eksternal

2. Pencarian informasi. Terjadi ketika konsumen mulai mencari informasi tentang produk yang akan mereka beli. Baik pencarian internal maupun eksternal.

3. Evaluasi alternatif. Tahap ini mulai dilakukan ketika konsumen memproses dengan mengevaluasi informasi yang sudah didapatkan. Pertama konsumen akan berusaha untuk memuaskan kebutuhannya. Kedua, konsumen akan mencari keuntungan dari produk tersebut. Ketiga, konsumen melihat masing- masing produk dan kemampuannya untukmenyalurkan manfaat.

4. Keputusan pembelian .Konsumen membentuk preferensi atas merek- merek yang menjadi pilihannya dan mencondongkan pilihannya terhadap merek yang paling disukai untuk dibeli. Konsumen akan membuat 5 keputusan dalam tahap ini yaitu, merek apa yang akan dibeli , dimana produk tersebut akan dibeli, berapa banyak produk tersebut akan dibeli, kapan produk tersebut akan dibeli dan cara pembayaran apa yang akan digunkan untuk membayar produk tersebut. 
5. Evaluasi pasca pembelian. Setelah konsumen melakukan pembelian dan menggunakan produk tersebut, konsumen akan dapat merasakan apakah konsumen cocok dengan produk tersebut atau tidak.

\section{METODE PENELITIAN}

Dalam penelitian ini, jenis penelitian yang dilakukan adalah penelitian kualitatif dengan metode deskriptif. Penelitian kualitatif adalah sebuah prosedur penelitian yang menghasilkan data deskriptif berupa kata- kata tertulis atau lisan dan perilaku yang diamati. Dalam makna lain penelitian kualitatif adalah jenis penelitian yang temuan- temuannya tidak diperoleh melalui prosedur statistik atau bentuk hitungan lainnya. Tulisan kualitatif memang menekankan pentingnya memahami bagaimana orang menginterpretasikan berbagai kejadian didalam kehidupan mereka (Santana, 2007).

Mardalis menyebutkan bahwa penelitian kualitatif yang bersifat deskriptif bertujuan untuk mendiskriptifkan apa- apa yang saat ini terjadi dan berlaku yang didalamnyaterdapat upaya mendeskripsikan, mencatat menganalisis dan menginterpretasikan kondisi- kondisi yang terjadi (Mardalis, 2007). Tujuan dari penelian deskriptif penelitian ini adalah untuk membuat deskripsi, gambaran atau lukisan secara sitematis, aktual dan akurat mengenai fakta- fakta serta hubungan antar phenomena yang diteliti (Najr, 2010).

Dalam penyusunan penelitian jenis data yang digunakan oleh peneliti adalah data primer dan data sekunder. Data primer diperoleh dari hasil wawancara langsung dengan para key person konsumen produk olahan salak dengan menggunakan daftar pertanyaan (kuesioner) dan pedoman wawancara. Sedangkan data sekunder adalah data yang diperbolehkan dari catatan atau sumber lain yang telah ada sebelumnya dan diolah kemudian disajiakan dalam bentuk teks, karya tulis, laporan penelitian, buku dan lain sebagainya.

\section{HASIL DAN PEMBAHASAN}

Produksi salak di kabupaten Tapanuli Selatan mengalami peningkatan hampir di setiap tahunnya, selain itu Kecamatan Angkola Barat adalah sentra tanaman salak di provinsi Sumatra utara dan dianggap daerah asal tanaman salak padangsidimpuan, dan dari daerah ini menyebar ke daerah-daerah lain sehingga saat ini tanaman salak padangsidimpuan dapat di jumpai hampir diseluruh kabupaten Tapanuli Selatan. Disamping itu, volume salak berbuah sepanjang tahun, apabila dalam satu tahun dapat memerikan hasil panen baik dan serentak dibeberapa daerah sedangkan permintaan akan buah salak menurun, maka banyak buah salak yang tidak laku terjual, dan harganya pun menurun (TIM Karya Tani Mandiri, 2010). 
Untuk menghadapi masalah tersebut masa simpan buah harus diperpanjang sehingga memiliki nilai tambah dan sekaligus meninggkatkan nilai ekonomisnya. Salah satu upaya adalah dengan proses pengolahan dan pengawetan salak segar menjadi produk olahan seperti dodol, wajid, manisan, asinan dan keripik salak (Anarsis, 2003). Petani atau pelaku agroindustri salak yang rasional akan memilih cabang usaha yang dapat memberikan keuntungan yang besar sehingga adanya perhitungan nilai tambah suatu usaha pengolahan buah salak akan membantu petani maupun agroindustri salak untuk mentukan jenis produk olahan yang lebih menjanjikan pendapatan tinggi dan keuntungan yang lebih baik.

UD. Salacca di dirikan atas inisiatif dari keadaan petani dan daya tahan salak yang hanya berkisar satu minggu khususnya salak padangsidimpuan, sehingga jika dibawa keluar kota atau di ekspor terkadang hanya setengah kondisinya yang baik, dan tidak bisa dibawa ke daerah yang jarak tempuhnya lebih dari satu minggu. Awal dari pengolahan buah salak adalah dodol salak dan kurma salak, dinama dengan adanya pengolahan salak ini petani bisa menjual salak ke pengumpulan. UD. Salacca mengolah menjadi berbagai macam makanan dan minuman, pada dasarnya salak hasil sortiran merupakan salak yang paling bagus usia kematangannya akan tetapi karena kulitnya sudah terkelupas membuat daya tahanya berkurang.

Adapun jenis usaha yang dikelola adalah pengolahan buah salak, adapun makanan dan minuman hasil olahan dari buah salak yang dihasilkan UD. Salacca adalah dodol salak "Namora”, kurma salak "Narobi”, agar-agar salak " Azizah”, dan sirup salak "natabo", minuman segar "Nagogo Drink”, keripik salak “ Naduma”, kecap Salak “On do”, madu salak "Najago", sari salak “ Narara”, manisan salak "Natonggi”, dan kopi salak "Calacca Kopi”.

Konsumen UD. Salacca terdiri dari masyarakat sekitar dan masyarakat yang berkunjung ke daerah Padangsidimpuan dan Kabupaten Tapanuli Selatan. Konsumen cendrung membeli olahan salak untuk buah tangan atau oleh- oleh, Konsumen produk Olahan salak meningkat $54 \%$ pada hari- hari perayaan seperti, Hari Raya Idul Fitri, Natal, Tahun Baru dan hari- hari besar lainnya.

Kualitas produk menjadi pertimbangan bagi konsumen dalam membeli sebuah produk seperti manfaat konsumsi selain rasa yang enak manfaat lain dari sebuah produk sebagai nilai tambah dari produk tersebut, seperti produk olahan salak mempunyai manfaat konsumsi yaitu salak merah yang mengandung anti oksidan, kalsium vitamin c, kemudian cocok untuk makanan diet, hal inilah yang menjadi pertimbangan bagi konsumen dalam keputusan untuk mengkonsumsi olahan buah salak. Daftar harga salak di Kecamatan Angkola Barat dapat dilihat pada Tabel 2. 
Persepsi Konsumen Dalam Keputusan Pembelian Terhadap

Produk - Produk Olahan Salak (Studi Kasus Ud.Salacca)

Sry Lestari

Tabel 2. Daftar Harga Salak di Kecamatan Angkola Barat

\begin{tabular}{|c|c|c|c|}
\hline Klasifikasi & Panen Raya & Normal & Paceklik \\
\hline Salak Super & $\begin{array}{l}\text { Rp 10.000 sampai } \\
\text { Rp15.000 per } \\
\text { kilogram }\end{array}$ & $\begin{array}{l}\text { Rp 15.000 sampai } \\
\text { Rp18.00o per } \\
\text { kilogram }\end{array}$ & $\begin{array}{l}\text { Rp18.000 sampai } \\
\text { Rp20.00o per kilogram }\end{array}$ \\
\hline Sedang & $\begin{array}{lr}\text { Rp3.00o } & \text { sampai } \\
\text { Rp7.00o } & \text { per } \\
\text { kilogram } & \end{array}$ & $\begin{array}{lr}\text { Rp7.0oo sampai } \\
\text { Rp10.ooo } \\
\text { kilogram }\end{array}$ & $\begin{array}{l}\text { Rp10.000 sampai } \\
\text { Rp15.000 per kilogram }\end{array}$ \\
\hline Campuran & $\begin{array}{l}\text { Rp 2.000 sampai } \\
\text { Rp5.00o per } \\
\text { kilogram }\end{array}$ & $\begin{array}{lr}\text { Rp 5.000 sampai } \\
\text { Rp8.ooo per } \\
\text { kilogram }\end{array}$ & $\begin{array}{l}\text { Rp8.000 sampai } \\
\text { Rp13.00o per kilogram }\end{array}$ \\
\hline Pamilian & $\begin{array}{lr}\text { Rp300 } & \text { sampai } \\
\text { Rp5oo } & \text { per } \\
\text { kilogram } & \end{array}$ & $\begin{array}{lr}\text { Rp500 } & \text { sampai } \\
\text { Rp100o } & \text { per } \\
\text { kilogram } & \end{array}$ & $\begin{array}{l}\text { Rp } 1000 \text { sampai } \\
\text { Rp700o per kilogram }\end{array}$ \\
\hline
\end{tabular}

Sumber: Wawancara dengan petani salak dan Pengumpul

Persepsi konsumen UD. Salacca memilih produk olahan salak dari faktor harga 30\% memilih produk olahan salak dibandingkan mengkonsumsi salak segar. Konsumen lebih cenderung untuk mengkonsumsi salak segar dimana sebesar 70 \% konsumen setuju akan hal tersebut. Harga produk olahan salak di pasaran berkisar Rp 5.000; hingga Rp 50.000; per bungkus, sedangkan salak segar berkisaran Rp 3.00o; hingga Rp18.ooo; dari segi harga, salak segar lebih terjangkau bagi konsumen. Aspek harga sangat dipertimbangkan dalam menentukan daya beli masyarakat terutama masyarakat taraf ekonomi menengah kebawah, apalagi terhadap produk yang bukan kebutuhan pokok. Sedangkan aspek sosial konsumen memilih konsumsi produk olahan salak karena sebagai produk olahan ciri khas daerah, sebagai oleh- oleh dan memberikan kontribusi kepada daerah dengan mencintai produk daerah. Selain itu secara tidak langsung konsumen dari daerah memperkenalkan produk ke daerah lain sebagai buah tangan. Aspek sosial lainnya budaya masyarakat merayakan harihari besar dengan mengkonsumsi makanan yang dianggap istimewa seperti kue- kue khas, minuman dan makanan yang hanya ditemukan di hari- hari besar atau sengaja di beli saat hari- hari besar. Selain itu kebiasaan saat berkunjung pada hari- hari besar membawa buah tangan.

Pertimbangan konsumen memilih olahan salak dibandingkan salak segar diantaranya ketahanan produk, dimana salak segar hanya bertahan 3 sampai 7 hari sangat beresiko untuk dibawa ketempat yang jauh, sedangkan produk olahan tahan beberapa bulan hingga tahunan. 
Selain itu praktis untuk dibawa, konsumen lebih memilih efisiensi untuk menikmati sebuah produk kemasan yang baik membuat konsumen lebih tertarik biasanya salak segar hanya di kemas dalam bentuk sumpit (karung daun berisi 2-6kg salak), karung atau keranjang yang pastinya berat untuk dibawa, duri- duri salak yang tajam beresiko untuk konsumen dan butuh tempat karena di padangsidimpuan dan Tapanuli Selatan belum ada packing salak yang baik atau salak segar dalam bentuk kemasan, sedangkan produk olahan salak sudah dikemas dalam bentuk kotak dan botol yang menarik, simpel dan praktis untuk dibawa.

Konsumen juga dapat lebih memperoleh jaminan kualitas karena sudah ada komposisi, lisensi halal, izin usaha dan tanggal kadaluarsa produk. Sedangkan konsumen yang memilih salak segar dibandingkan produk olahan karena membutuhkan produk yang alami, tidak membutuhkan waktu yang lama untuk dikonsumsi, jarak tempuh dekat serta membutuhkan produk yang organik. Konsumen tetap membeli salak segar meskipun membeli produk olahan salak kareana yang memengaruhi konsumen memilih bukan karena harga dan kualitas akan tetapi kondisi konsumen tersebut. Konsumen yang ingin membawa oleh- oleh ketempat yang jarak tempuhnya membutuhkan waktu yang lama lebih memilih membeli produk olahan salak dibanding salak segar, akan tetapi sebagian konsumen tetap membeli salak segar dan produk olahan salak secara bersamaan, dan sebagaian konsumen hanya membeli salak segar. Informasi terkait produk olahan salak rata- rata konsumen memperolehnya dari orang lain, sebagian dari iklan radio, acara TV yang pernah menampilkan proses pengolahan salak dan dari pameran yang pernah diikuti.

\section{KESIMPULAN}

Persepsi konsumen terhadap produk olahan salak positif. konsumen memilih sesuai dengan keadaan dan kebutuhan, hal tersebut sangat tergantung keadaan masing- masing konsumen. Walaupun sudah ada produk olahan salak, salak segar tetap menjadi pilihan bagi konsumen. Kualitas produk, harga dan faktor sosial menjadi pertimbangan bagi konsumen dalam mengambil keputusan membeli produk olahan salak.

\section{DAFTAR PUSTAKA}

Anarsis W, 2003, Analisis Fungsi Produksi Agri Bisnis Salak dan Indutri Pangan Olahannya, Bogor: J. Pengkajian dan pengembangan teknologi pertanian.

Fure,H, 2013, Lokasi, Keberagaman Produk, Harga Dan Kualitas Pelayanan Pengaruhnya Terhadap Minat Beli Pasar Tradisional Bersehati Calaca, Jurnal EMBA,Vol. 1, No 3, pp.273-283 
Kotler, P., \& Keller, K.L. 2012, Marketing Management $14^{\text {th }}$ Edition. England:education Limited

Kotler, P., \& Amstrong, G, 2010, Principles Of marketing $13^{\text {th }}$ Edition.New Jersey:Pearson Education, Inc.

Manahan P. Tampubolon, 2008, Perilaku keorganisasian, Bogor: Ghalia Indonesia.

Mardalis, 2007, Metodologi Penelitian Suatu pendekatan Proposal, Jakarta: Bumi Aksara.

Moh Najr, 2010, Metode Penelitian, Bogor: Ghalia Indonesia

Oladepo, O. L. \& Abimbola, O. S, 2015, The Influence Of Brand Image And Promotion Mix On Consumer Buying Decision (a study of bevera consumers in Lagos States, Nigeria). British Journal of Marketing Studies, Vol3, No. 2, pp. 97-109.

Purwati Setiawan H., \& Rohmawati, 2012, Pengaruh Harga Dan Kualitas Produk Terhadap Keputusan Pembelian Motor Honda Matic Beat (Studi kasus pada PT.Nusantara Solar Sakti). Jurnal Ekonomi dan Informasi akuntansi (Jenius), Vol. 1, no. 3, pp. 1-10

Septiawan Santana, 2007, Metode Penelitian Kualitatif, Jakarta: Yayasan Obor Indonesia.

Tim Karya Tani Mandiri, 2010, Pedoman Budi Daya Buah Salak, Bandung: CV. Nuansa Auliya.

Urfana, Milliatina, \& sembiring, B. K, 2013, Analisis Pengaruh Faktor Kebudayaan, Sosial, Pribadi, Dan Psikologi Terhadap Keputusan Pembelian Makanan Cepat Saji Pada Konsumen Kentuky Fried Chiken (KFC) Walikota Medan . Media Informasi Manajemen, Vol. 5, No. 5, pp.383-387. 